\title{
2 Mona and the Political-Cultural Economy of Independent Galleries
}

\author{
Adrian Franklin
}

\section{Introduction}

Contemporary independent galleries are among the most rampant, cashed up, bon viveurs of the global art scene, and, as the projects mostly of the super-rich, they surf the countervailing flows of cash from the same neoliberal policy levers that cause public arts funding to dry up. There's no sense of crisis among them as a sector unless we factor in the much-anticipated crash in contemporary art prices and/or the demise of neoliberalism. Yet it's difficult to see them as separable from the art world they operate in, and easy to see them as increasingly significant to it. Thus, it is possible to situate them in the relational and historical narrative of the extended exhibitionary complex (Smith, 2012) where they figure as present day manifestations of private collectors who have always been a mainstay of arts and museum collections, and whose collecting cultures and collections have recently been reconfigured around different art, different art markets and different relationships with artists, gallerists, curators and a proliferation of exhibitionary platforms - including public art museums everywhere. The key word here then is extension rather than tension between public and private. A question that interests me is how different private collectors are as exhibitors and whether their relative freedom from museological norms, public scrutiny and political control (in those places where it's possible), combined with their emotional passion (as noted by Walter Benjamin [2007] in his essay on book collecting), can be or has been, marshalled to create new experiences of art in museums, and if so what value this might have. So, this is my basic approach here. My answer will be that mostly they have not, but there are signs that they can, or they could in collaboration with others.

This chapter provides a sketch of this kind, based around two questions. As central philanthropic figures, how have private collectors' contributions and values changed as they have shifted from silent partners to active museum builders? And how have they shaped the cultural ecology they found themselves in? I suggest that there are three important processes in play that guide how answers can be found to these questions. First, through the multiple ways in which they have become entangled in the spiralling growth and extension of contemporary art into more popular cultural forms of taste and consumption. Second, through 
the collaborative role they have played in experimenting with new exhibitionary platforms, and third by bringing contemporary art to new regions, places and communities that did not have them before.

The arrival world-wide of many new private museums has been breath-taking: there are now 317 (with active, living collector-founders), 70 per cent of which were built after 2000 and many more are anticipated (Larry's List, 2016). There are now 20 in Australia and eight in New Zealand and private collectors have opened museums of contemporary art in many more places where once there were none. For example, in November 2017 Indonesia's first museum of modern and contemporary art, Museum MACAN (Modern and Contemporary Art in Nusantara), the project of its owner Haryanto Adikoesoemo, will open in Nusantara, West Jakarta with Thomas J Berghuis (ex-Director of Chinese art at Guggenheim New York) as Director (Larry's List, 2016). Plans are afoot in 2019 for Taiwanese collector Pierre Chen to build a new private museum in the mountains outside Taipei (Larry's List, 2019). As a sector, they are characterised as much by their differences and variation as their commonalities but for reasons that will become clear, I shall concentrate mostly on their special if not defining association with contemporary art in the past 20 years or so.

\section{Typology}

So first, how different are they and what are the sources of their variation? Many, perhaps the majority of, private initiatives, are modelled in curatorial and experiential terms on conventional public museums (White Rabbit + Indigo Slam, Sydney; Tarrawarra, Victoria; The Long, Shanghai); others embody the more critical and radical stance of the not-for-profit art spaces - Mona (Museum of New and Old Art), Tasmania; DRAF (David Roberts Art Foundation, London; Museum of Everything, London) - which actively oppose convention in some way; while other owners in collaboration with key artists use their collections to become overt shapers/manipulators of taste, art markets and city art worlds (The Saatchi Collection, London; The Broad, LA). The latter are both examples of private museums that have invested heavily and support art in their respective cities/regions; while Mona, Sherman and White Rabbit bring international art into cities that might not have it, or so much of it otherwise. At another extreme, the public museum model is being reconfigured as 'art depots' and 'warehouse' concepts, as new private enterprises, in collaboration with city authorities, tap into the expanding sources of art in private collections to combine publicly funded storage and professional services (much in demand) in exchange for rights to exhibit to the public. The Public Art Depot which opened at the Boijmans van Beuningen Museum in Rotterdam in 2018, claims that for the first time, anywhere in the world, a major museum's entire art collection (not just a tiny fraction of it) will always be on public display (Kennicott, 2016; Harris, 2016; Bechtler and Imhof, 2014). As with Mona much of the taxonomy and chronology go, and while it does not have Mona's anti-museum pretensions, it is new in exposing the back rooms and back business - such as restoration, cleaning and other art care (core aspects of curation) to the public gaze.

Most are strong institutions that are open and public facing. A few, such as the tax 
sheltering antics of Peter Brand in the USA, mostly or often closed, have become public scandals. In sum, private museums do not inevitably oppose public museums in operation, function or exhibitionary strategy, though they are often a means of extending the work of the not-for-profit art spaces which operationalised critiques of the modern museum as a governmental, cultural-political project (Roberts, 1997; Smith, 2012; Franklin, 2000).

\section{The Rise of Contemporary Art, its Collection and Display}

Once an avant-garde, minor, oppositional and largely self-referential element of the art world, contemporary art became a dominant force, particularly after 2000, as a more mainstream and fashionable focus for social, cultural and political expression - high art-lite, as Stallabrass (2006) characterised it. Mathew Collings (2001) was even able to describe the UK as an 'Art Crazy Nation' and by this he meant crazy for contemporary art, suddenly. Since then there have been many changes in the way art has been collected and supported by the independents with implications for the relationships and exchanges between independent and public spheres of exhibition.

From around the art market crash of 1990, private art collecting changed profoundly from being spread across the mainstream historic periods of art, typically exhibited in major public art galleries, to a growing concentration on contemporary art. By 201490 per cent of the top 200 art collectors globally were collecting contemporary art as compared with only 58 per cent in 1990. All other period genres dwindled and have since dwindled even further. Auction sales in contemporary art increased by 24.2 per cent between 2012 and 2013 alone, totalling US\$3.39 billion and representing 44 per cent of Sotheby's and Christie's total 2013 sales (Deloitte, 2014).

The rising importance of contemporary art drove a collecting fever with such dramatically rising prices that after 2008 its status as a big-ticket investment for the super-rich was barely rivalled (Deloitte, 2014). It was simple: 'The Artnet C50 Index, which combines performance data from 50 top contemporary and post-war artists, advanced 434 per cent from the start of 2003 through 2014, beating most asset classes including gold, fine wine and stocks'. Deloitte showed that against the S\&P 500's total return of 7 per cent, for 2014, contemporary art delivered compound annual returns of 15 per cent. By 2013, the world's population of Ultra-High Net-Worth Individuals (UHNWI) (holdings of US\$30+ million) reached an all-time high of 199,235 individuals with a combined wealth of US\$27.8 trillion. A new wave of collector art museums became a growing financial possibility when around 9 per cent of UHNWI's assets began to be held in art, most of it in contemporary art.

Far from being driven by investment considerations, it seems that a passion for art and philanthropy had certainly not waned among those who became collectors. According to Deloitte (2014: 84) only 3 per cent of collectors' sole motive for buying art was investment, a point supported by Thornton (2008: 83) who reports widespread disapproval of speculation within the contemporary art world. For most (76 per cent), the primary motive was a mix of 
passion and investment, while for 21 per cent of collectors the sole motive was the passion of collecting contemporary art. According to Art market monitor, 46 of the top 200 art collectors have acquired and operate their own exhibitionary space and according to a recent Larry's List survey of 3,400 major collectors, 37 per cent are active in public institutions and 12 per cent have opened their collection to a public online platform. Only 4 per cent of collectors state that tax breaks motivated them to set up their museums (Larry's List, 2016). According to Deloitte (2014) 'art and philanthropy' is a key area of concentration for one third of wealth managers in 2015.

The Report on Private Art Museums produced by Larry's List (2016) shows that the passion and enthusiasm of private museum owners is also particular and aesthetically focussed. Unlike Mona or White Rabbit, most tend to collect, commission and support a narrow range of artists in depth, often young and emerging artists from their region or nation. The in-depth regional patronage of artists provides the basis for involvement and exchange in wider, global exhibition, curation, loaning and other exchanges such as funding educational workshops and the travel of exhibited artists. Wang Wei and Liu Yiqia who established the Long Museum in Shanghai also reported how in China they struggle as inexperienced museum owners with professionally untrained staff and how training, advice and visits are among the things exchanged internationally across the public-private spheres.

Such attention from collectors of contemporary art pumped massive amounts of money into its production - globally - creating tensions with public galleries who lacked the space to exhibit the growing numbers of works loaned to them privately, or the resources to continue to collect contemporary art in-depth themselves (Falckenberg, 2014). Since the point of contemporary art was very much to be seen in its day, many collectors [and artists] wanting their works on view publicly began to look at other strategies for its exhibition (Bredin, 2010). Eli Broad is widely quoted as saying that if he had given his collection to a prestigious institution such as the MoMA in New York, '95 per cent would be in the basement. I want the work to be seen'. Schuker (2008) describes a 'firestorm over private museums' as collectors in the US abandoned public art museums - their traditional source of supply - and as massive extensions were built everywhere, to win them back. However, it also worked the other way, as Falckenberg (2014) observes: '[public museums] no longer want complete collections. Only a few works, or groups of works, are preferred. This is one important reason why so many private museums have emerged in recent years'. In many regions beyond the developed West, there were very few public galleries or not-for-profits to exhibit this art anyway. So, some of the first museums across Asia and the Middle East, for example, were pioneered by private collectors. This was aided by new tax breaks or development licenses from nations such as China who wished to augment the cultural content of its cities.

From the 1960s onwards, Western contemporary artists had been an important source of criticism of public art museums, many setting up their own not-for-profit art spaces in conjunction with alternative/independent curators and private foundations such as Dia Art Foundation, New York. Donald Judd's collaboration with Dia, culminating in the Chinati 
Foundation in Marfa, Texas and after his death the Judd Foundation sites in New York and Marfa, established the significance of permanent installations for major artists whose work was strongly context bound with the circumstances and spaces of its creation (Stockebrand, 2010; Judd, 2016). Other artists (including Dan Flavin, John Chamberlain, Robert Irwin, Richard Long, Roni Horn, Carl Andre) came to Marfa and further established the notion of the artist curator/installer and the permanent installation of art. This was compounded in the UK for the YBAs generation, who took to curating and exhibiting their own shows in the wake of the near total collapse of the London gallery sector in 1990. Prior to the subsequent dramatic expansion and growth of contemporary art after 2000 therefore, an alternative exhibitionary and collecting culture was established among contemporary artists, with a variety of models and platforms, including the biennales, private gallery shows, pop-up shows and art fairs.

After 2000, celebrity contemporary artists and their galleries looked beyond the public art museum and especially to the new independent museums, once it became clear that the public sector were less able to provide optimum public exposure for ongoing commercial artist reputations. Exploiting super-rich collecting fever, henceforth they exchanged access to their best works for guaranteed exposure by private collector museums where alluring architecture was considered a bonus (Falckenberg, 2014; Gnyp, 2015). The hugely upbeat art fairs, biennales and festivals of this period allowed for commercial exchange and new alliances between collector-museum owners and the artists they were keen to collect. In these, artists negotiated more exhibitionary and curatorial collaboration and control than had been possible before. The new alliances offered collectors a more creative role than the hitherto silent partner arrangements of the Getty collecting era. Out of these new relationships, often forged in the festive exuberance of the biennale and art fair, the normative exhibitionary formats and didactic aims of most public museums could be and were challenged or by-passed. It would thus be premature to conclude that the historic connections between private collectors and public museums fell apart simply because the former had now built their own museums and different experiences of art. The evidence so far suggests the opposite.

Hanquinet and Savage's (2012) study of Belgian art museums demonstrated that a majority of visitors, regardless of social class, maintained an image of art museums as places of educative leisure. It revealed unexpected and new dynamics and change, and a growing taste for perspectives critical of conventional art museums (see also Stallybrass, 2006; Smith, 2009; 2012; 2015). As Hanquinet and Savage show, it was less the case that new tastes derived merely from 'social background', and more the case that they emanated from 'cultural and experiential' fields. Those attending other art institutions and art forms were looking for something beyond educational leisure and were finding it in a more distributed set of exhibitionary platforms, from art hotels, pop-up exhibitions, public spaces and bars (Hanquinet and Savage, 2012). Out of these new experiences and contexts new dispositions were discernible, combined with a renewed critique of the modern didactic museum as detached from its spectators and everyday life (Hanquinet and Savage, 2012: 52). 
Contemporary art itself formed a new connective tissue to important areas of contemporary life and reached out to new publics using less coded, more familiar techniques of popular culture, not least through advertising (Collings, 2001; Papastergiadis, 2012; G. Harris, 2013; Foster, 2015). Hal Foster's typology of contemporary art's main themes: the abject, the precarious, the traumatic, the archival and the lost, enabled him to argue that it tracks and comments on key experiences of contemporary life as a modified, caustic avantgarde. He argued that it reached out using techniques of 'mimetic exacerbation' and 'mockery' (also derived from the historic repertoire of public culture) directly to knowing, new audiences (Foster, 2015: 78-96).

Mona (see Plate 3) deliberately curated contemporary art to unleash this agency that is quietened wherever it is exhibited in emotionally tranquilised white cubes. It aimed to provoke and activate using a constant stream of arresting and astonishing art works, often very large, with movement/action/sound and smell. Mona hit on the idea of the human body, and the subjects of sex and death as highly inclusive themes, though they are also significant themes of much contemporary art, dealt with using grotesque realism (Connelly, 2003). At the same time, it removed anything that encumbered active emotional engagement: chronology, taxonomy, repetition as well as direction and instruction were removed. Works were theatrically lit to enhance their impact and paired with other art in juxtaposition, to effect that other theatrical trope: the dissociative disordering of the time of art. A well credentialed technique of carnivalesque theatre (Bakhtin, 1984; Bristol, 1983), this gives artists a compelling way of using elements of the past that can threaten, haunt and disturb more confident forms of power in the present. In doing this, Mona was also creating artistic expression itself. David Walsh (the owner of Mona) called Mona an anti-museum because it actively opposed and reversed many of the aims and practices of conventional art museums (Franklin, 2014). Mona also mocked the art world, art, artists and even its own art collection through its communications and catalogues in order to break down the aura of the museum (Roberts, 1997). Inciting visitors to laugh at art and artists brought the museum experience down to earth and knocked art off its pedestal. It was felt that by doing this it helped to reset the relationship between art and its public and permitted visitors to see art in a new way (Capon, 2013; Franklin, 2014).

\section{What Difference Does This Make?}

While the social composition of Mona's visitor profile was highly stratified and dominated by the educated middle classes, visitor experience was far less socially stratified (Franklin and Papastergiadis, 2017: 9). Although 75 per cent of Mona's visitors were tertiary educated and 25 per cent non-tertiary, there was little significant difference in overall experience: 97 per cent of the tertiary educated said their overall experience was positive compared with 94 per cent of the non-tertiary educated.

For those types of experience where one might think, following Bourdieu, that middle- 
class visitors had a far greater disposition and access to the art at Mona, the differences in their reporting of them was not always remarkably different from the non-tertiary educated. For example, 80 per cent of the tertiary educated agreed with the statement 'Visiting Mona has made me think about a lot of things' as compared with 79 per cent of the non-tertiary educated. Similarly, 82 per cent of the tertiary educated agreed with the statement 'My visit to Mona has enriched my life' compared with 74 per cent of the non-tertiary educated. Even with respect to the capacity to enjoy art, reported experiences at Mona do not support the dominant view that there is a gulf between the educated middle classes and the working classes: 77 per cent of non-tertiary educated visitors agreed with the statement 'Mona has increased my enjoyment of art' as compared with 78 per cent of tertiary educated visitors. Their experiences may not be the same, but they are not strongly polarised. If anything, new forms of pleasurable experiences to be had with art were forging a new kind of convergence (Franklin, 2014; Franklin and Papastergiadis, 2017) (see Table 2.1).

Table 2.1 Mona visitors' experiences of art

\begin{tabular}{lll}
\hline 'Compared to other museums ... at Mona' & Tertiary per cent & Non-Tertiary per cent \\
\hline experienced art in a different way & 95 & 96 \\
freer to choose their experience of art & 87 & 89 \\
were more confronted by art & 56 & 56 \\
experienced different types of art more easily & 82 & 85 \\
increased enjoyment of art & 78 & 77 \\
made them think more & 80 & 80 \\
were more inspired & 78 & 74 \\
were more affected at & 84 & 74 \\
life changing experience & 20 & 30 \\
enriched lives & 82 & 74 \\
\hline
\end{tabular}

Source: Franklin and Papastergiadis 2016 pp7-10

\section{Extending the Exhibitionary Complex Spatially}

In Western nations, as elsewhere, private foundations and museums are typically if not exclusively distributed into a wider range of community locations than most major public institutions and therefore should be seen to be filling in ecological gaps as much as competing. Along with the not-for-profits many private museums and foundations are located in peri-urban, lower-status locales. Thus, billionaire owners Kerr and Judith Neilson graced the (then) shabby streets of Chippendale, Sydney with the popular White Rabbit Gallery and now its extension, Indigo Slam - see Figures 2.1 and 2.2, a place where Neilson talks of taxi drivers refusing to go, even as late as 2007. The Zabludowicz Collection of Contemporary Art chose an old Methodist chapel in Chalk Farm, London, while DRAF is in a former carpet warehouse behind a charity shop 'on a grubby main drag' in Kentish Town. David Walsh chose to place Mona in Glenorchy where he grew up in social housing, a suburb in the top decile of socioeconomic disadvantage, and Haryanto Adikoesoemo has built Museum 
MACAN, in Kebon Jeruk, West Jakarta - which is a decidedly low status and possibly even disreputable district. Others are established in rural areas (e.g. Kunstwerk, in Nussdorf, Germany) often linking up romantic movement upland trails in relatively poor agricultural districts, or in remote or island locations (the Bennesse Art Site on Naoshima, Japan, for example). Requiring touristic journeys involving separation from the everyday and demanding significant commitments of time, these locations are often deliberately chosen to foster receptivity to new ideas and enhance more sensual encounters with art - as well as bringing new business opportunities to depressed peripheral economies (Franklin, 2003, 2018; Smith, 2009). Similar spatial patterns can be found in the Middle East and other parts of Asia.

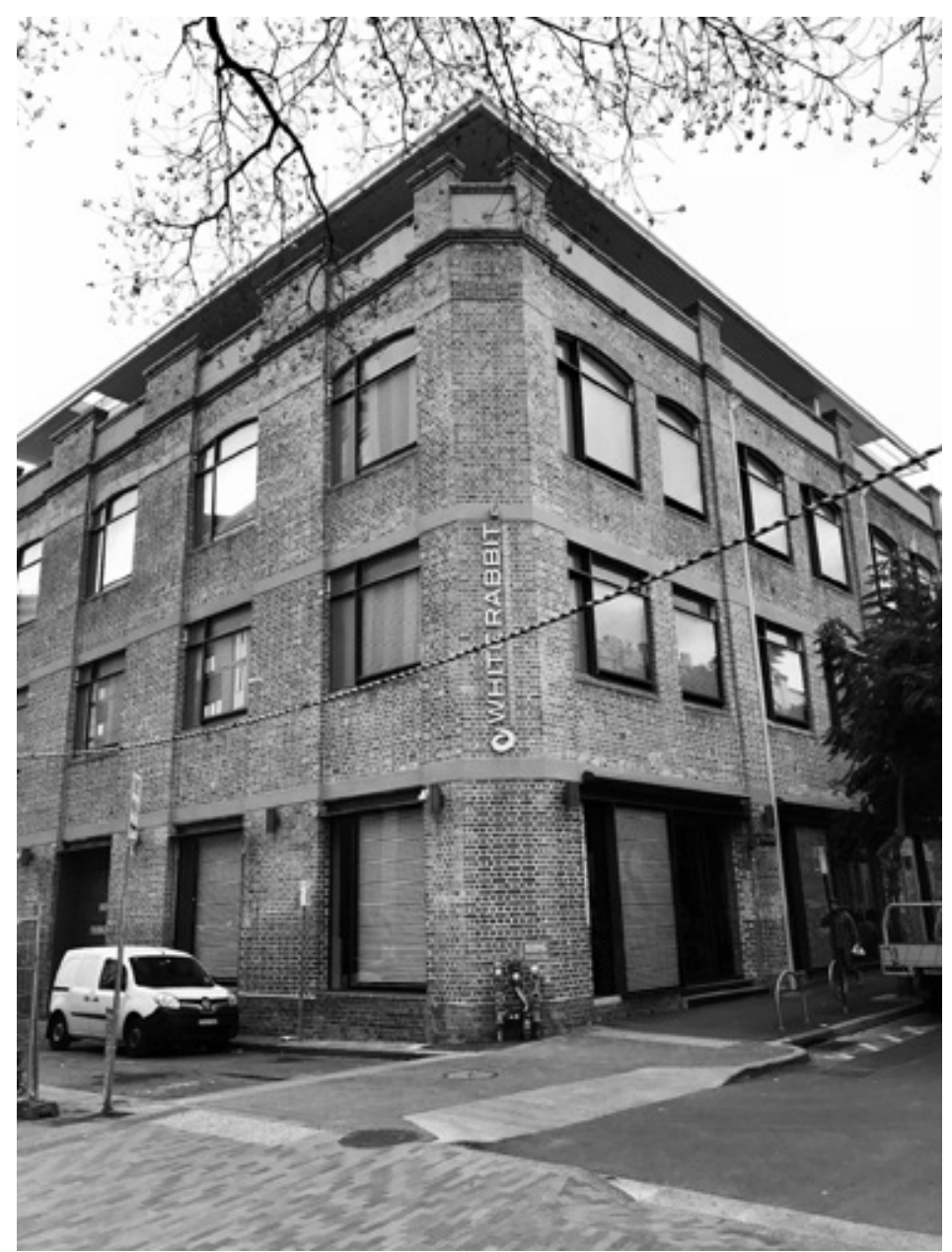

Figure 2.1 A former Rolls-Royce showroom converted into an art gallery of Chinese contemporary art. White Rabbit, Sydney. Photo Adrian Franklin 


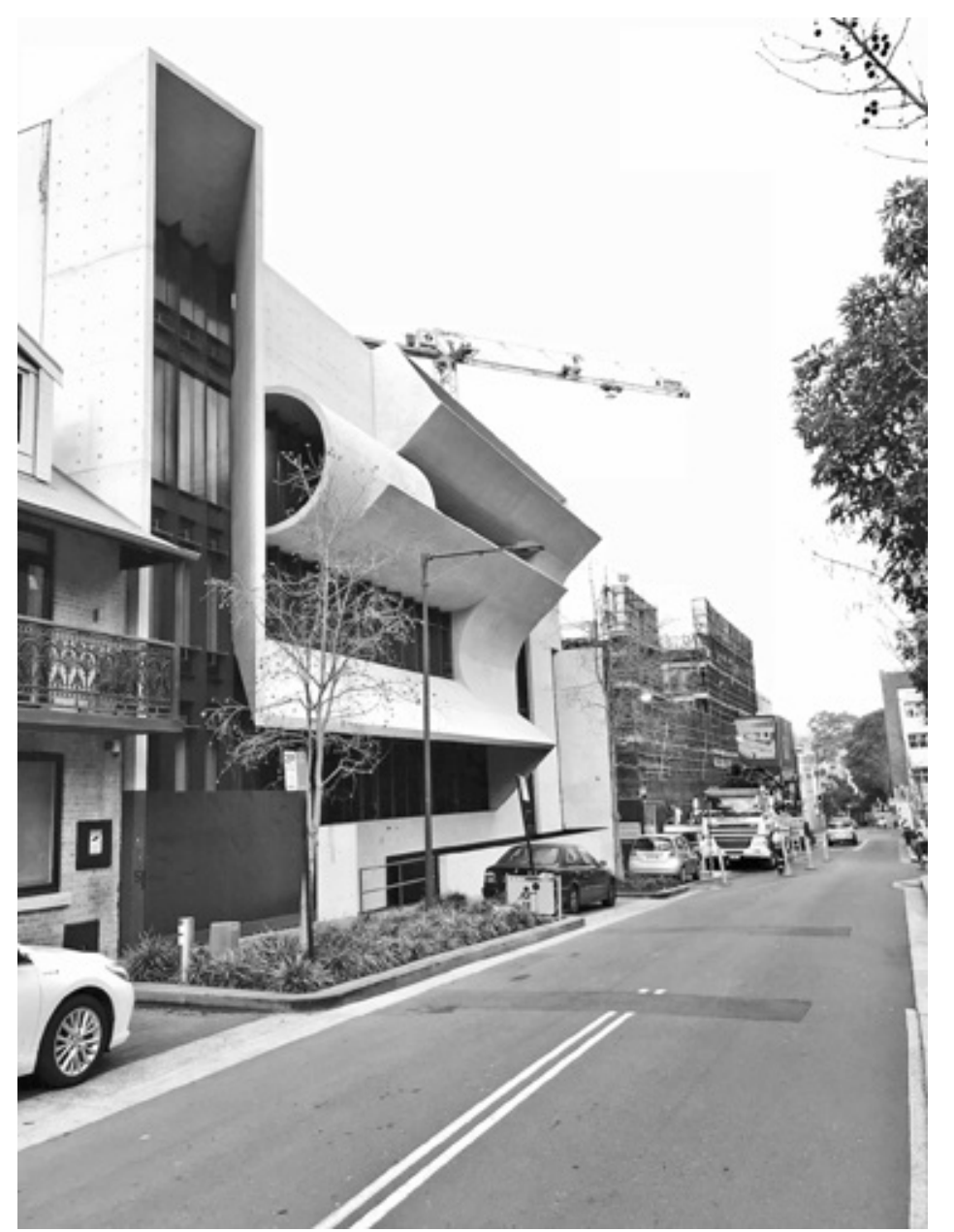

Figure 2.2 Indigo Slam being inserted into a Chippendale terrace. Photo: Adrian Franklin

\section{Impact on New Localities}

A recent study of Mona was interested in whether it had an impact on museum-going among the residents of a city such as Hobart and the socially deprived, adjacent city of Glenorchy where contemporary art of this type and scale was new. ${ }^{1}$ There is a section of the local community in Glenorchy for whom Mona is variously experienced as strange, alienating, baffling and in some cases offensive (Booth et al., 2017). From our study of local residents in Hobart and Glenorchy we also know that more non-tertiary educated visitors (18 per cent) than tertiary educated visitors (12 per cent) only visited Mona once since it opened. This may suggest that some were curious but not lured into a further engagement with Mona's antimuseum. More significant, however, are the numbers of local residents that appear to have seen something of value at Mona. Among those from Hobart and Glenorchy who had been to Mona at least once, 63 per cent of the non-tertiary educated had carried on visiting Mona after their first trip there. Forty-nine per cent said they 'visit Mona regularly now' and 14 per cent said they visit it 'more than when it first opened'. Local visitation to Mona is dominated by those with tertiary education, as they do elsewhere. Among those from Hobart and Glenorchy who had been to Mona at least once, a higher proportion (76 per cent) of those with a tertiary education have carried on visiting Mona. Sixty per cent are now Mona 
regulars and 16 per cent visit Mona more frequently than when it first opened.

However, while the pattern of attendance may not have changed (tertiary educated people dominating the art-going public), arguably it is the shape and proportions of that pattern that are more critical when we judge whether a new museum has changed museum-going in any way. In 2009-2010 the Australian Bureau of Statistics found that 20 per cent of people with non-tertiary qualifications had attended an art gallery across Australia in the previous year. While only 44 per cent of Australians with a Bachelor degree had attended an art gallery in the previous year, 49 per cent of the non-tertiary educated population of Hobart and Glenorchy reported an engaged relationship with Mona (either visiting regularly since it first opened [38 per cent] or 'more than when it first opened' [11 per cent]). So, Mona can claim an attendance rate for its local non-tertiary educated citizens that exceeds the rate of those with bachelor's degrees nationally. Similarly, Mona's collection and exhibitions are rich in contemporary art, museums of which are typically less popular than traditional fine art galleries. To put that in context, a 2012 national survey in France found that while 23 per cent of the population had been to a museum of fine art in the previous 12 months, only 13 per cent had been to a museum of contemporary art (Bigot et al., 2013). By these measures Glenorchy now looks better than France. Since 2011 when Mona opened, only 26 per cent of Glenorchy's residents have never been to Mona. Of those who had been (74 per cent of locals), 41 per cent have become regular visitors and 16 per cent now visit Mona more than when it first opened. Put another way, we can say that by 2015, 31 per cent of Glenorchy's residents were regular goers and 12 per cent were going more than they were when it first opened - more than three times better than France.

Finally, we might ask what impact has all this going to Mona had? Does Mona contribute much to life in the two cities? We asked respondents how they would describe Mona's contribution to their city life on a scale from zero to ten. Eighty-four per cent of respondents ranked Mona's contribution as 6 or above with 40 per cent ranking it 10. This suggests that art museums (public museums as well as private collector museums) can (and should) be built in places of social disadvantage where their democratising impact can be impressive and not just in central city cultural precincts.

\section{Exchanges Between Private and Public}

At the very point in September 2007, when Mona concluded several years of thinking and discussion about its museum aims, it is clear that it aimed to extend its impact beyond the museum walls and lead exchanges with public partnerships. These aims were clearly established in the following way (Fraser, 2013):

- Improvement to cultural facilities in Tasmania

- Cross-branding with Moorilla

- Educational facility for schools 
- Academic resource and research facility

- Creative environment for artists/writers in residence

- Patronage of contemporary arts and culture

- Self-marketing: sufficient generator of controversy to continually engage media attention

- Put a rocket up public collections/generate Government interest in community driven projects with possible funding outcomes

All of these came to fruition in some way, but spectacularly so in the case of the last element. While Mona is widely credited with innovating its hallmark deployment of the 'festive register', the liminoid gallery space and a recombination of visual art with music, in fact, these originated from successful experimental collaborations with several public cultural bodies and across a range of public spaces. Until this experimentation proved successful its owner had favoured a far more serious intellectual tone (Franklin, 2014; 2019). The successful midsummer festival Mona Foma and midwinter festival Dark Mofo have been reported elsewhere (Franklin, 2014 and 2019, respectively).

Equally, the Venice Biennale inspired exhibition Theatre of the World (TOTW) was a collaboration with a state public institution, the Tasmanian Museum and Art Gallery (TMAG). In the eyes of TMAG Senior curator, Jane Stewart, this collaboration with an affluent and daring private collector museum brought four advantages. First, its star curator, Jean Hubert-Martin, gave more emphasis to the value of art objects in themselves and 'challenged the perceived barrier' at TMAG that their objects required very high standards of historical research before they could be placed in the public domain. These expensive and time-consuming processes prevented a large amount of its material from ever seeing the light of day and even its most exciting possessions remained unseen. Martin evidently trusted the public to find ways to engage with the objects in this exhibition, especially when they were allowed to resonate with other art objects and works.

Second, through this collaboration, a local municipal museum (and its public) was given unprecedented national and international exposure and experience through collaborations with an individual collector, a prominent French curator and star of the biennale circuits, with the Fondation Maeght in France and with two major national public galleries (the National Gallery of Victoria and the Art Gallery of New South Wales). The exhibition and its Tasmania curatorial team subsequently travelled to the private gallery, La Maison Rouge, in Paris, where they led a seminar at its opening.

Third, curators believed that a 30 million funding package for redevelopment related to their success with TOTW. It increased the confidence of government in supporting an institution consistent with what they hoped was Hobart's new-found reputation as an edgy arts city. In that process, TMAG was also remade in the likeness of Mona's darkened, sensual atmospherics. Which increased public interest. As Stewart (2016) observes, 'whether or not it was consciously acknowledged, our part in the "junking of the chronological corset" (to quote the title of one of the essays in the TOTW catalogue) must have given the impression 
that TMAG was open to "stepping out"'.

Fourth, their experience set TMAG on valuable new directions. With its new international connections, with its increased traffic in cultural tourism and media interest for Tasmania; and a new-found openness to new models of working and working with others it was able to:

- nurture the new contact made with European historians, curators and collectors;

- run with the world's response to Tasmania and its public collection;

- reach out to the influx of art tourists to - and media interest in - Tasmania that Mona has inspired;

- remain open to a visual and museological debate about the role of public museums in today's busy and ever-connected 'theatre' of a world.

Mona may or may not be an exceptional case here and this is especially apparent in the assembly of major exhibitions. The flow of exchanges between the Sherman Contemporary Art Foundation and public institutions in Sydney has been continuous as it pursues its focus on 'private funding in public spaces', recently staging the equally successful East Meets West at the Art Gallery of New South Wales, where its historic focus on Asian art chimed with new aims of the AGNSW. A collaborative, public meets private approach is built into its very practice as a foundation (Sherman, 2009). For example, international curators are invited to take a single artist from their collection and research other collections nationally and internationally in order to identify and access significant related works by the same artists for new exhibitions (Heckmuller, 2014: 15).

Equally, the summer season of major exhibitions in Australia, 2015-2016 demonstrated an extraordinary mix or public-private exchange. Gilbert and George at Mona, Grayson Perry at Sydney's Museum of Contemporary Art (MCA), and Andy Warhol and Ai Weiwei at the National Gallery of Victoria (NGV) were heavily dependent on private collaboration and enthusiasm. Equally, 52 per cent of private museums exhibited works from other collections in 2015 and for 20 per cent of them borrowed works constituted more than half of the works exhibited (Larry's List, 2016: 40). While such sketches of collaboration and exchange are possible, details of the iterative unfolding of collaboration work, exchanges of practices and values, adoptions, failed and successful experiments, negotiations and new partnerships are never routinely documented, seldom reported and rarely researched. This is clearly a field of research than can and should be developed in the future.

\section{Conclusion}

Independent galleries are widely perceived as deeply problematic (Hatton and Walker, 2000; A. Harris, 2013; Miles, 2013): it is alleged that they vie for sovereignty over cultural authority, they threaten to undermine the capacity of public art museums to deliver on their core responsibilities (especially in the field of contemporary art) (Schuker, 2008), and they deepen the marketisation (and manipulation) of all relationships within the art world and with 
art publics (Ellis, 2008; Smith, 2009; A. Harris, 2013; Hatton and Walker, 2000; Miles, 2013). While this chapter acknowledges the truth of these claims, albeit that some of them are exaggerated, it also shows that these impacts belong to a much wider series of changes in the social and commercial life of contemporary art, where, in fact private collectors and their museums are still an integral part of the extended exhibitionary complex. The chapter has shown that they are very far from their characterisation as neoliberal successors to the public museum. The paper argues that there has been a shift in the role that collectors play in this complex, from silent partners to active museum builders and from supporters of the conventional modern museum to facilitators of alternatives to it (though many remain conventional too). Some, such as Mona, have framed new museum aims around a longstanding artist-led critique of the art museum. It has sought to change the experience of art and to alter the hierarchical and authoritative relationship between the museum and its publics as well as experiment with making art more accessible and pleasurable. While seeking to oppose convention in a lively way, Mona, alongside the majority of other independent galleries, is actively engaged with many other public museums in a complex of exchanges and interdependencies that looks set to continue.

\section{Notes}

1 Franklin, A., O’Connor J. and Papastergiadis, N (2012) 'Creating the Bilbao Effect: MONA and the Social and Cultural Coordinates of Urban Regeneration Through Arts Tourism’ Australian Research Council Linkage Grant, LP120200302.

\section{References}

Bakhtin, M. (1984) Rabelais and His World, Minneapolis: University of Minnesota Press.

Bechtler, C. and Imhof, D. (2014) Future Museum, Switzerland: JRP-Ringier.

Benjamin, W. (2007) ‘Unpacking my library: A talk about book collecting’. In: H. Arendte (ed.) Illuminations: Essays and Reflections, New York: Brace and World.

Bigot, R., Daudey, E., Hoibian, S. and Müller, J. (2013) La Visite des Musees, des Expositions et des Monuments, Paris: Credoc.

Booth, K., O’Connor, J., Franklin, A.S. and Papastergiadis, N. (2017) 'It’s a museum, but not as we know it: Issues for local residents accessing the Museum of Old and New Art', Visitor Studies, 20(1): 10-32.

Bredin, L. (2010, November 26) 'Behind the scenes in private museums', Financial Times. https://www.ft.com/content/b1309d24-f823-11df-887500144feab49a.

Bristol, M.D. (1983) 'Carnival and the institutions of theater in Elizabethan England', ELH, 50(4): 637-65.

Capon, E. (dir.) (2013) The Art of Australia. A Three-Part TV Documentary, Sydney: Australian Broadcasting Corporation.

Collings, M. (2001) Art Crazy Nation, London: 21Publishing.

Connelly, F. (ed.) (2003) Modern Art and the Grotesque, Cambridge: Cambridge University Press.

Deloitte (2014) Art and Finance Report 2014, New York: Deloitte Luxembourg and ArtTactic.

Ellis, A. (2008, February) 'The problem with privately funded museums', The Art Newspaper. http://www.theartnewspaper.com/article.asp?id=7509.

Falckenberg, H. (2014, April 14) 'The art world we deserve', Financial Times. https://www.ft.com/content/498f5cca-bfce-11e3-b6e8-00144feabdc0.

Foster, H. (2015) Bad New Days: Art, Criticism, Emergency, New York: Verso.

Franklin, A.S. (2000) Anti-Museum, London: Routledge.

Franklin, A.S. (2003) Tourism, London: Sage.

Franklin, A.S. (2014) The Making of Mona, Melbourne: Penguin.

Franklin, A.S. and Papastergiadis, N. (2017) 'Engaging with the anti-museum? Visitors to the Museum of Old and New Art', Journal of Sociology, 53(3): 670-686.

Franklin, A.S. (2018) 'Art tourism: A new field for tourist studies’, Tourist Studies, 18(4): 399-416.

Franklin, A.S. (2019) 'Where “art meets life”: Assessing the impact of Dark Mofo, a new mid-winter festival in Australia’, Journal of Festive Studies, 1(1): 106-127.

Fraser, M. (2013) 'Introduction and explanatory notes to MONA archive 2007’, personal communication to the author from Mark Fraser, Mona Museum, Director 2005-2011.

Gnyp, M. (2015) The Shift: Art and the Rise to Power of Contemporary Collectors, Stockholm: Art and Theory Publishing. 
Hanquinet, L. and Savage, M. (2012) “Educative leisure’ and the art museum’, Museum and Society, 10(1): 42-59.

Harris, A. (2013) 'Financial artscapes: Damien Hirst, crisis and the City of London’, Cities, 33: 29-35.

Harris, J. (2013) ‘Introduction’. In: J. Harris (ed.) Globalization and Contemporary Art, London: Wiley Blackwell.

Harris, G. (2016, February 9) 'Rotterdam museum to rent out public space to wealthy collectors', The Art Newspaper. https://www.theartnewspaper.com/news/rotterdam-museum-to-rent-out-public-space-to-wealthy-collectors.

Hatton, R. and Walker, J. (2000) Supercollector: A Critique of Charles Saatchi, London: Ellipsis.

Heckmüller, S. (2014) Private. A Guide to Personal Art Collections in Australia and New Zealand, Sydney: Art Australia.

Judd, D. (2016) Donald Judd's Writings, New York: Judd Foundation.

Kennicott, P. (2016, February 11) 'A Microsoft billionaire gives the public a rare view of his art', Washington Post. https://www.google.com/search? $\mathrm{q}=\mathrm{A}+$ Microsoft+billionaire+gives+the+public+a+rare+view+of+his+art\%E2\%80\%99\%2C+Washington+Post.8\#x0026;oq=A+Microsoft+billionaire+ 8.

Larry’s List/AMMA (2016) Private Art Museums Report, Vienna: Modern Arts Publishing.

Larry's List (2019, January 27) 'Taiwanese mega-collector Pierre Chen wants to open a private museum in the mountains outside Taipei’, Art Collector News. https://www.larryslist.com/report/Private\%20Art\%20Museum\%20Report.pdf.

Miles, M. (2013) ‘Art and culture: The global turn’. In: E. Grierson and K. Sharp (eds.) Re-Imagining the City, Chicago: UCP.

Papastergiadis, N. (2012) Cosmopolitanism and Culture, Cambridge: Polity.

Roberts, J. (1997) 'The crisis of critical postmodernism'. In: A.W. Balkema and H. Slager (eds.) The Photographic Paradigm. Vol 12 of Lier and Boog: Series of Philosophy of Art and Art Theory, Amsterdam: Rodopi.

Schuker, L.A.E. (2008, April 4) ‘Firestorm over private museums’, The Wall Street Journal. https://www.wsj.com/articles/SB120727433942088537.

Smith, T. (2009) What Is Contemporary Art? Chicago: University of Chicago Press.

Smith, T. (2012) Thinking Contemporary Curating, New York: Independent Curators International.

Smith, T. (2015) Talking Contemporary Curating, New York: Independent Curators International.

Stallybrass, J. (2006) High Art Lite, London: Verso.

Stewart, J. (2016) 'Collaborating with Mona on theatre of the world’ The Mona Effect. Retrieved from http://themonaeffect.wordpress.com.

Stockebrand, M. (2010) Chinati, Marfa Texas: The Vision of Donald Judd, Marfa: Marfa Foundation in association with Yale University Press.

Thornton, S. (2008) Seven Days in the Art World, London: Granta. 